\title{
ROADMAP OF EXCISE ON CIGARETTE POLICY PACKAGE IN INDONESIA: AN ANALYTICAL HIERARCHY PROCESS APPROACH
}

\author{
Noor Syaifudin* \\ Fiscal Policy Office \\ Ministry of Finance of Republic of Indonesia \\ E-mail: soib2000@yahoo.com
}

\begin{abstract}
As the need of the state revenue to satisfy the national budget, thus the high excise revenue will be required, whilst on the other side the consumption of cigarette needs to be controlled. This confirms that the increase in excise rate will affect in curbing the cigarette consumptions. As several stakeholders will be impacted in the reduction of its economic output to the overall economy, thus the Government of Indonesia needs to shift this impacted industries to other sectors which will obtain a better output. The analysis was done by valuing the stakeholder's weight based on the Roadmap of Tobacco Industry on the long term pace, which will be point out more on the health, then labor and state revenue on third priority. Criteria for evaluation were employed such as economic efficiency, operational feasibility, financial feasibility, and political viability.

Finally, this paper recommends an integrated roadmap of excise policy package for controlling the cigarette consumptions in order to satisfy and ensure the national budget, and managing the cigarette industries. The proposal comprises of, by sequence, i.e.: encountering the illicit cigarette, increasing the excise tariff, non tariff policy, shifting off the impacted sectors, simplifying the cigarette industry structure, and introducing new potential excised objects.
\end{abstract}

Keywords: related stakeholders, policy alternatives, policy criteria, AHP, roadmap of excise policy package

\section{Introduction}

To fulfill its task and function, the government has to secure its revenue sources, one of those are from excise. As the demand on state budget increases, it is expected that excise revenue moves up in parallel. In the state budget 2009, it is anticipated that the state revenue from excise will rise up to 54.5 trillion rupiahs or $1 \%$ of GDP. This calls for appropriate excise policy that is capable to satisfy the state objective of meeting its budget demand.

\section{Research Methods and Design}

All related information and data including regulations and law are collected until 2009. The AHP method is implemented under several steps. First, meetings and Focused Group Discussions are conducted to meet a comprehensive understanding on the problem and background of the excise on cigarette policy. Second, questionnaires with relevant stakeholders are employed to identify the policy alternatives under the selected criteria. Third, the Analytical Hierarchy Process (AHP) method employed to obtain quantitative measurement of the analysis and lay down the priority of the policy alternatives.

\section{Roadmap of Tobacco Industry}

In the short term, starting from year 2007 to year 2010, first priority will be given to the workforce aspect, state revenue the second priority and health the third priority. This means that in the wake of the financial crisis in 1997-1998, whose impact was predicted to last until 2010, the government will pay more attention to employment issue over that of state revenue and health.

\footnotetext{
${ }^{*}$ Corresponding author
} 
In the medium term, from 2010 to 2015 , state revenue will receive first priority, followed by health aspect and the workforce aspect. The government was confident that in 2010 the impact of the financial crisis would be revamped and forecast the demand for increased state revenue as the need of the government expenditures increase - excise is considered as one priority mechanism to bridge the fiscal gap. In the meantime, however, the fact that health aspect will become second priority mean that excise tariff will need to move up to a moderate notch and that non tariff regulation be more intense to guarantee consideration on health aspect from tobacco industry in terms of advertisement, smoking venue, etc.

The long term strategy of 2015 - 2020 will see health aspect as the first priority, and the second and third priority go to workforce and state revenue respectively. In this term, the production of cigarette will be tightly controlled and some of the industry will be prepared to shift to the other industry. The total volume of cigarette production will be pegged at the ceiling level of 260 billion cigarette sticks per year. Product market will be geared toward export market over domestic one.

\section{Stakeholders of Tobacco Industry}

The cigarette industry has a very wide impact to the economy and the actors behind and related to this industry. The related and interest of each stakeholder can be depicted below:

1. Ministry of Labor: their main priority is on the unemployment level, and the cigarette industry is thought as the industry which absorbs many workers, particularly the hand rolled cigarette and the farmers.

2. Ministry of Health: healthy level of the community is the main interest. Their priorities are the increase in excise tariff to the highest level, the push on production, limitation in advertising and non smoking area.

3. Ministry of Industry: their main interest is the total investment on the industry in Indonesia. As the cigarette industry is concerned as the sunset industry, their priority is on how to provide policy which is hit the industry in the short run, meanwhile the complementary industry must be prepared. Their most concern today is how they can succeed in performing the roadmap of tobacco industry.

4. Ministry of Finance: the main interest is how to satisfy the budget to finance its expenditure. Since excise is one of the stable and important sources of revenue, the increase of excise tariff will be the highest priority. Due to the capability to stipulate excise tariff is lying on them, they will eager to have a blue print for the excise policy. This blue print will guide them in determining the excise tariff policy in the future without any hard opponent from the other stakeholders.

5. Cigarette Industry: their interest is to maintain their industry and profit. They will strongly argue to the low level of excise tariff with many incentives which should be provided by government such as tax cut as the labor intensive industry and for their export level.

6. Anti Tobacco NGO: their interest is to increase the healthy level of the people by reducing the cigarette consumption. They proposed a highest level of excise tariff, with many restrictions which should be applied. In the short run, they will ask for the roadmap for excise policy. They requested the roadmap due to their interest to intervene to satisfy their proposal. They asked for the significant diminishing of cigarette consumption by obtaining all the potential policy that can be applied such as: restricted area to smoke, content level of cigarette, advertising regulation and ban for young smoker.

\section{Policy Alternatives}

Due to concern on the need of providing comprehensive and deep policy package, the below policies package is proposed.

\section{Simplify the Tobacco Industry Structure}

- Providing barrier to entry

- Tightening requirements for Cigarette Company to operate and no transfer of permit.

- Bundling/merging the small cigarette company to be a bigger cigarette company 
The process of bundling of the small cigarette can be facilitated by the local government in order to meet the requirements of capital, minimum production, and management.

\section{Shifting off the related industry}

The shifting can be conducted on the gradual and step by step approach to the related sectors. The several steps can be proposed: capital and technology assistance, improvement of the human capital, the improving of tobacco, clove and cigarette export through promotion, trade mission, and diplomatic channel, and the use of earmark fund in assisting the shifting process.

\section{Increase the Excise Tariff}

\section{a. Rationale for Government Interventions}

There are at least two reasons of the government interventions on the cigarette sectors, what it is called as externalities, as follow: firstly, market failures on the cigarette consumption. Secondly, the asymmetric information to the smokers, mostly the youth, the poor and the cigarette initial user.

b. Impact of the increase on cigarette price.

The increase on cigarette price through the increase on excise will provide two advantages, both economically and health. Therefore, the increase of cigarette price is considered as the most effective way to curb the damage on the health as the use of tobacco. World Bank predicted that the increase by 10 percent of the tax on cigarette will increase the total state revenue by 7 percent on average. The study showed that the increase of the excise will not reduce the state revenue from the excise on cigarette. By imposing high excise tariff as the reduction on the quantity of the cigarette sold, however the levied tax is higher.

\section{c. Impact to the responsive group.}

It is needed to increase on excise tariff which is purposed: to simplify excise policy to support of controlling the cigarette consumption, to give a direction of the excise policy in the future, to synergize the stakeholder on the excise policy formulation and to ease the state revenue projections.

\section{Add New Potential Excised Object}

Given the two steps that are recommended to add new potential excised objects, as follows:

\section{i. Provide proper research and projections}

The characteristics of the mentioned goods which therefore considered appropriate to be the new excise objects are as follows:
a. Cement
b. Soft Drink

\section{ii. Provide a strong legal basis}

\section{Encounter Illicit Products}

In Indonesia, since the illicit problems mostly come from domestic industries, the handling should be paying more attention on the local. Below are the several actions that can be done by the Government of Indonesia to curb the potential illicit products, as the complementary of several actions above:

a. The use of earmarking fund to provide anti illicit products operation

b. Introducing a method to distinct the legal and illegal product

\section{Non tariff policy}

The recommended ways which are the non tariff policy can be mentioned such as:

a. Restrictions on Smoking

b. Health Information and Counter Advertising

c. Restriction on Tobacco Industry Advertising and Promotion 


\section{Policy Criteria}

\section{Economic Efficiency}

This criterion evaluates the policy alternatives based on economic perspective. The first concern is how the policy can be benefited to the community and then, the evaluation analyzes the cost for implementing the policy.

\section{Operational Feasibility}

This criterion measures whether option outcomes achieve their purpose. The basis of the operational feasibility criterion is the reliability of the course of actions and its effectiveness on attaining the purposes and the results identified for the alternatives.

\section{Financial Feasibility}

This criterion assesses the financial feasibility of the policy and the projects following the implementation of the policies. This criterion also takes into account the ability of the government to finance the policy and its implication as well as the investment feasibility for the private investors.

\section{Political Viability}

This criterion measures policy or program outcomes in terms of impact on relevant stakeholders. The criterion considers the alternatives on the basis of its acceptability or can be made acceptable to the stakeholders. The measurements in the political viability are often subjective and less quantifiable, but the support from the relevant stakeholders to the success of the policy alternatives will be much demanded.

\section{Policy Evaluation}

Results of AHP analysis

As the result of the matrix calculation, the eigenvectors of the policy based on the sequencing of the priority are:

\section{Policy Alternatives Based on Rank}

\begin{tabular}{|l|l|c|}
\hline Rank & \multicolumn{1}{|c|}{ Policy Alternatives } & Eigenvector \\
\hline $\mathbf{1}$ & Encounter Illicit Products & 0,1896 \\
\hline $\mathbf{2}$ & Increase the Excise Tariff & 0,1805 \\
\hline $\mathbf{3}$ & Non tariff policy & 0,1638 \\
\hline $\mathbf{4}$ & Shifting off the related industry & 0,1626 \\
\hline $\mathbf{5}$ & Simplify the Tobacco Industry Structure & 0,1570 \\
\hline $\mathbf{6}$ & Add New Potential Excised Object & 0,1463 \\
\hline
\end{tabular}

\section{Policy Recommendations}

The followings are the proposed policies under the Roadmap of Excise on Cigarette Policy Package in Indonesia that have been evaluated using the four criteria by employing Analytical Hierarchy Process method:

\section{Short Term Policy Package (2011 - 2016):}

\section{Encountering the Illicit Cigarette}


- The use of earmarking fund to provide anti illicit products operation.

- Introducing a method to distinct the legal and illegal product.

2. Increasing the Excise Tariff

- Increasing the excise tariff gradually by applying the specific tariff which is taking into account the macroeconomic situation and the cigarette industry condition.

- Simplifying the excise administration and supervision.

\section{Medium Term Policy Package (2016 - 2020):}

3. Non Tariff Policy

- Restrictions on Smoking.

- Health Information and Counter Advertising.

- Restriction on Tobacco Industry Advertising and Promotion.

- Determine the content on the cigarette.

\section{Shifting off the Impacted Sectors}

- Capital and technology assistance.

- Improvement of the human capital.

- The improving of tobacco, clove and cigarette export

- The use of earmark fund in assisting the shifting process.

\section{Long Term Policy Package (2020 - 2025):}

\section{Simplifying the Cigarette Industry Structure}

- Providing barrier to entry

- Tightening requirements for cigarette company

- Bundling/merging the small cigarette company

\section{Introducing New Potential Excised Objects}

- Prepare proper research and projections.

- Potential Excised Objects:

- Tire

- $\quad$ Soft Drink

- Provide a strong legal basis.

\section{REFERENCES}

Adioetomo, Sri Moertiningsih, Triasih Djutaharta, and Hendratno.(2005). Cigarette Consumption, Taxation, and Household Income: Indonesia Case Study. Economics of Tobacco Control Paper No. 26: $1-31$.

Barber, Sarah, Sri Moertiningsih Adioetomo, Abdillah Ahsan, and Diahhadi Setyonaluri.(2008). Ekonomi Tembakau di Indonesia. Depok: Lembaga Demografi: Universitas Indonesia.

Blecher, Evan.(2009). The economics of tobacco control: prices and taxes. Mumbai: American Cancer Society.

Carl V. Paton, David S. Sawick. (1986). Basic Methods of Policy Analysis and Planning. Englewood Cliffs, New Jersey: Prentice Hall, 1986.

Chaloupka, Frank J., Grossman, Michael, Tauras, John A.(1996). Public Policy and Youth Smokeless Tobacco use. National Bureau of Economic Research. 
Cnossen, Sijbren. (1983). Comparative Tax Studies: Essays in Honor of Richard Goode" Rotterdam: North-Holland Publishing Company.

- .(1977). Excise System: A Global Study of The Selective Taxation of Goods and Services. Maryland: The John Hopkins University Press.

David Merriman, Ayda Yurekli, and Frank J. Chaloupka. How big is the worldwide cigarette-cigarette smuggling?

Gupta, Prakash C. (2001). The public health impact of tobacco. Current Science.

Hana Ross, Frank J. Chaloupka.(2001). Economics of Tobacco Control.

Marimin MSc, Prof. DR. Ir. (2004). Teknik dan Aplikasi: Pengambilan Keputusan Kriteria Majemuk. Jakarta: PT Grasindo.

Ministry of Industry of Republic of Indonesia.(2007). Roadmap Industri Hasil Tembakau (IHT). Kesepakatan Hasil Tembakau, Jakarta: Direktorat Jenderal Industri Agro dan Kimia.

Saaty, T.L.(1994). Fundamentals of Decision Making. Pitssburgh, USA: RWS Publications.

Sumarno, Simon Bambang, and Mudrajad Kuncoro. Struktur, Kinerja, dan Kluster Industri Rokok Kretek: Indonesia, 1996-1999. 1-23.

Yurekli, Ayda. Design and Administer Tobacco Taxes. World Bank Economics of Tobacco Toolkit. 